\title{
Effects of renal sympathetic denervation on blood pressure and glycaemic control in patients with true resistant hypertension: results of Polish Renal Denervation Registry (RDN-POL Registry)
}

\author{
Jacek Kądziela ${ }^{1}$, Aleksander Prejbisz², Katarzyna Kostka-Jeziorny ${ }^{3}$, Dariusz Dudek ${ }^{4}$, Krzysztof Narkiewicz ${ }^{5}$, \\ Jerzy Sadowski ${ }^{6}$, Andrzej Lekston ${ }^{7}$, Aneta Gziut ${ }^{8}$, Andrzej Więcek ${ }^{9}$, Paweł Buszman ${ }^{10}$, Andrzej Kleinrok ${ }^{11}$, \\ Janusz Kochman ${ }^{12}$, Danuta Czarnecka ${ }^{13}$, Andrzej Januszewicz ${ }^{2}$, Adam Witkowski ${ }^{1}$ \\ 'Department of Interventional Cardiology and Angiology, Institute of Cardiology, Warsaw, Poland \\ 2Department of Hypertension, Institute of Cardiology, Warsaw, Poland \\ ${ }^{3}$ Department of Hypertension, Angiology, and Internal Medicine, Poznan University of Medical Sciences, Poznan, Poland \\ ${ }^{4} 2^{\text {nd }}$ Department of Cardiology, Jagiellonian University, Krakow, Poland \\ ${ }^{5}$ Department of Hypertension and Diabetology, Medical University of Gdansk, Gdansk, Poland \\ ${ }^{6}$ Department of Cardiovascular Surgery and Transplantation, John Paul II Hospital, Jagiellonian University, Krakow, Poland \\ ${ }^{7}$ Silesian Centre for Heart Diseases (SCHD), Zabrze, Poland \\ ${ }^{8}$ Department of Clinical Hospital of the Ministry of Internal Affairs, Warsaw, Poland \\ 'Department of Nephrology, Transplantation, and Internal Medicine, Medical University of Silesia, Katowice, Poland \\ ${ }^{10}$ American Heart of Poland, Centre for Cardiovascular Research and Development, Katowice, Poland \\ ${ }^{11}$ Department of Cardiology, John Paul II Hospital, Zamosc, Poland \\ ${ }^{12}$ Department of Cardiology, Medical University of Warsaw, Warsaw, Poland \\ ${ }^{13} 1^{\text {st }}$ Department of Cardiology and Hypertension, Jagiellonian University, Krakow, Poland
}

\section{Abstract}

Background and aim: The assessment of percutaneous renal sympathetic denervation (RDN) efficacy in patients with true-resistant hypertension (true-RH) in a newly established net of Polish centres (RDN-POL Registry).

Methods and results: Forty-four patients with true-RH (23 men, mean age 52.3 years) with daytime systolic blood pressure (SBP) in ambulatory blood pressure monitoring (ABPM) $\geq 135 \mathrm{~mm} \mathrm{Hg}$, on $\geq$ three antihypertensive agents, including diuretic, underwent RDN and completed 12-month follow-up. Mean reductions of office SBP/diastolic blood pressure were -23.8/-10.0, $-12.5 /-4.6$, and $-12.6 /-6.1 \mathrm{~mm} \mathrm{Hg}$ at 3, 6, and 12 months, respectively (all significant except diastolic at 6 months). Diabetes was the only predictor of office SBP reduction at 6 months (OR 9.6, 95\% Cl 1.4-66.5, p < 0.05). Mean 24-h SBP change was $-8.3 \mathrm{~mm} \mathrm{Hg}$ at 6 months and $-4.6 \mathrm{~mm} \mathrm{Hg}$ at 12 months. Increased $2 \mathrm{~h}$-glucose in oral glucose tolerance test was the only predictor of 24-h SBP reduction at 6 months (OR 1.24 for $10 \mathrm{mg} / \mathrm{dL}$ glucose increase, $95 \% \mathrm{Cl} 1.04-1.48, \mathrm{p}<0.05$ ). At 12 months, 24-h SBP change predictors were: baseline office SBP (OR 4.93 for $10 \mathrm{~mm} \mathrm{Hg} \mathrm{SBP}$ increment, 95\% Cl 1.01-24.1, $\mathrm{p}<0.05$ ) and $2 \mathrm{~h}$-glucose (OR 1.47, 95\% Cl 1.08-2.00, p < 0.05). In ABPM responders, significant reduction of $2 \mathrm{~h}$ glucose was found as compared to the non-responders ( -45.8 vs. $-7.7 \mathrm{mg} / \mathrm{dL}, \mathrm{p}<0.005)$.

Conclusions: The RDN-POL Registry demonstrated moderate blood pressure decrease after RDN. The predictors of blood pressure reduction were diabetes, 2 h-glucose, and baseline office SBP. Analysis of ABPM responders indicates a probable positive impact of RDN on glycaemic control.

Key words: resistant hypertension, renal denervation, registry, sympathetic nervous system, diabetes

Kardiol Pol 2016; 74, 9: 961-968

Address for correspondence:

Jacek Kądziela, MD, PhD, Department of Invasive Cardiology and Angiology, Institute of Cardiology, ul. Alpejska 42, 04-628 Warszawa, Poland, tel: +48 223434272 , fax: +48 2234345 06, e-mail: kadziela@ikard.pl

Received: 28.12.2015 Accepted: 31.03.2016 Available as AoP: 05.05.2016

Kardiologia Polska Copyright (C) Polskie Towarzystwo Kardiologiczne 2016 


\section{INTRODUCTION}

Percutaneous, catheter-based renal sympathetic denervation achieved by the application of discrete, low-dose radiofrequency energy to the renal artery adventitia has been reported to reduce blood pressure (BP) by the impairment of renal sympathetic efferent and afferent signalling [1-3]. Both in the "first-in-man" Symplicity HTN-1 trial and in the randomised Symplicity HTN-2 study, significant reductions of the office blood pressure measurements were demonstrated. The lower changes observed in 24-h ambulatory BP monitoring (ABPM) - not mandatory in the study protocol — raised some concerns about the probability of recruitment of subjects with pseudo-resistant hypertension and its potential impact on the results. Moreover, the recently published randomised Symplicity HTN-3 trial results did not confirm better reduction of BP after renal denervation in comparison to pharmacological treatment, starting the discussion about the future of this method [4-6].

The Renal Denervation Polish Registry (RDN-POL Registry) was initiated independently on other registries and set up for the evaluation of the effects of the denervation procedure on office and 24-h BP measurements in patients with proven resistant hypertension and declaring good treatment adherence (as assessed by the referring doctor), in a newly established net of eleven Polish centres equipped with the Symplicity renal denervation system.

\section{METHODS}

Inclusion criteria comprised: age 18-70 years, true resistant hypertension defined as systolic BP (SBP) of $160 \mathrm{~mm} \mathrm{Hg}$ or greater (an average of three office BP readings) and mean of systolic daytime pressure confirmed in 24-h ABPM of $135 \mathrm{~mm} \mathrm{Hg}$ or greater, treatment with maximum tolerated and unchanged doses of at least three antihypertensive drugs (including a diuretic) for a minimum of 4 weeks prior to screening, favourable anatomy of both renal artery trunks (minimal diameter of $4 \mathrm{~mm}$ and length of $20 \mathrm{~mm}$ ) and an estimated glomerular filtration rate (eGFR) of at least $45 \mathrm{~mL} / \mathrm{min}$, using the Modification of Diet in Renal Disease (MDRD) study equitation [7]. All patients before the confirmatory ABPM were interviewed again about treatment adherence.

The exclusion criteria were as follows: a) renal artery abnormalities (significant renal artery stenosis, prior angioplasty or stenting, multiple renal arteries); b) known secondary hypertension: primary aldosteronism (based on plasma renin activity/aldosterone ratio), pheochromocytoma (based on urine methoxy catecholamine concentrations), coarctation of the aorta or Cushing disease (according to the local standard practice); c) myocardial infarction, unstable angina pectoris, or a cerebrovascular accident within 6 months of the screening visit or widespread atherosclerosis, with documented intravascular thrombosis or unstable plaques; d) chronic heart failure New York Heart Association (NYHA) class III or IV; e) type 1 diabetes mellitus; $f$ ) the presence of an implantable cardioverter defibrillator or pacemaker; f) treatment with any of the following medications: systemic corticosteroids, fludrocortisone, warfarin; g) any serious medical condition, which, in the opinion of the investigator, may adversely affect the safety and/or effectiveness of the participant or the study (i.e. clinically significant peripheral vascular disease, abdominal aortic aneurysm, bleeding disorders such as thrombocytopenia, haemophilia, or significant anaemia, or arrhythmias such as atrial fibrillation, respiratory support); h) pregnancy current or planned within the follow-up (female participants of childbearing potential had to have a negative serum or urine human chorionic gonadotropin (pregnancy test prior to enrolment); i) known, unresolved history of drug overuse or alcohol addiction; and j) current enrolment in another investigational drug or device trial.

All patients provided written, informed consent and the study was approved by the institutional ethics committee.

Forty-seven patients were submitted to the Registry by 11 centres. Forty-four of them with true-resistant hypertension and complete bilateral renal denervation were included into the database and have been followed-up for 12 months. Three patients were not entered: two of them had very low baseline office SBP (140 and $133 \mathrm{~mm} \mathrm{Hg}$, respectively), and one patient underwent incomplete renal denervation (less than four ablations in each artery). In all patients, the daytime SBP levels in ABPM were higher than $135 \mathrm{~mm} \mathrm{Hg}$, confirming resistant hypertension; however, in eight of them the mean of three office SBP measurements was less than $160 \mathrm{~mm} \mathrm{Hg}$ (151-159 mm Hg). The scientific committee decided not to exclude these patients from the registry.

Follow-up data after 3,6 , and 12 months were obtained from 41, 43, and 42 patients, respectively. One patient died between 3- and 6-month visit due to intracranial haemorrhage, and another one did not agree to have a control visit at 12 months.

\section{Study procedures}

Office blood pressure measurements and ABPM, clinical evaluation, adverse event incidence and general chemistries (creatinine, sodium, potassium) were assessed at baseline and repeated on follow-up assessment at 1, 3, 6, and 12 months, excluding ABPM which was not obligatory at 1 month. Blood samples for all biochemical evaluations were taken after overnight fasting, and eGFR was calculated using the MDRD equation. Glucose concentrations were measured in a fasting state and in oral glucose tolerance test (OGTT) $2 \mathrm{~h}$ after $75 \mathrm{~g}$ glucose administration. OGTT was performed in 34 patients before and in 29 patients 6 months after the procedure. Haemoglobin A1c (HbA1c) level was assessed in 29 patients at baseline and in 33 patients at 6 months.

\section{Office BP measurements}

Blood pressure was measured with the patient in the sitting position after a 5-min rest, using an automated device. Three 
consecutive readings were performed. If the difference between readings was higher than $10 \mathrm{~mm} \mathrm{Hg}$, further measurements were taken so as to obtain three consecutive consistent readings. The average of these three readings was recorded.

\section{Ambulatory BP measurements}

In all patients, ambulatory BP measurements were recorded; readings were obtained every 15 min during the day (06:00$-22: 00 \mathrm{~h}$ ) and every $30 \mathrm{~min}$ during the night (22:00-06:00 h). Division on sleep and activity periods was made after the recoding based on data from patient diary. Recordings had to be repeated when less than $70 \%$ of the readings were valid.

\section{Renal denervation}

The treatment catheter (Symplicity, Ardian Inc., Palo Alto, CA, USA) was introduced into each renal artery via femoral access. A detailed description of the procedure can be found elsewhere [1]. Briefly, discrete, radiofrequency ablations of 8 watts or less were applied, lasting 2 min each, to obtain 4-6 ablations separated both longitudinally and rotationally within each renal artery. During ablation, the catheter system monitored tip temperature and impedance, altering radiofrequency energy delivery in response to a predetermined algorithm. The first two procedures performed in each site were supervised by one of two interventionalists from the coordinating centre, who were experienced with the procedure.

\section{Statistical analysis}

The results throughout are presented as mean and standard deviation except for the number of antihypertensive drugs, which is depicted as median and interquartile range given in brackets. For comparison between measures before and after denervation, t-test for variables with normal distribution and non-parametric Wilcoxon signed-rank test for variables without normal distribution was employed. Multivariate stepwise backward regression analysis of key characteristics that may predict increased SBP response was performed. Baseline variables entered into the model were: age, sex, office SBP, ABPM daytime SBP, body mass index, baseline heart rate $(\mathrm{HR})$, number of antihypertensive medications, eGFR, hypercholesterolaemia, diabetes, glucose level in 2-h OGTT, and number of ablations. Data analysis was carried out using statistical application SAS System version 9.2.

\section{RESULTS}

\section{Subjects' characteristics}

Forty-four patients (23 men, 21 women) with mean age $52.3 \pm 9.2$ years were entered into the registry database. Baseline characteristics of these patients are shown in Table 1. Both office SBP and diastolic BP (DBP) were significantly higher in patients with increased HR (HR over the mean of $80 \mathrm{bpm}$ ) as compared to subjects with HR below 80 bpm (181.7 \pm 23.1 vs. $168.6 \pm 11.9 \mathrm{~mm} \mathrm{Hg}$,
Table 1. Clinical characteristics of the studied group

\begin{tabular}{|c|c|}
\hline Males & $23(52 \%)$ \\
\hline Age [years] & $52.3 \pm 9.2$ \\
\hline Obesity (BMI > 30 kg/m²) & $22(50 \%)$ \\
\hline $\mathrm{eGFR}\left(\mathrm{mL} / \mathrm{min} / 1.73 \mathrm{~m}^{2}\right)$ & $83.1 \pm 22.8$ \\
\hline Diabetes & $12(27 \%)$ \\
\hline Diabetes - insulin treated & $5(42 \%)$ \\
\hline Hyperlipidaemia & $23(52 \%)$ \\
\hline Office SBP [mm Hg] & $173.7 \pm 18.1$ \\
\hline Office DBP [mm Hg] & $99.8 \pm 15.7$ \\
\hline Ambulatory 24-h SBP [mm Hg] & $153.5 \pm 16.9$ \\
\hline Ambulatory 24-h DBP [mm Hg] & $90.4 \pm 20.3$ \\
\hline Ambulatory daytime SBP [mm Hg] & $158.8 \pm 16.8$ \\
\hline Ambulatory daytime DBP [mm Hg] & $96.2 \pm 16.5$ \\
\hline Ambulatory night-time SBP [mm Hg] & $141.4 \pm 21.3$ \\
\hline Ambulatory night-time DBP [mm Hg] & $83.0 \pm 16.7$ \\
\hline No. of antihypertensive medications & $5.7 \pm 1.4$ \\
\hline \multicolumn{2}{|l|}{ Type of antihypertensive medication: } \\
\hline ACE inhibitor/ARB & $59 \% / 66 \%$ \\
\hline Beta blocker & $95 \%$ \\
\hline Aldosterone receptor antagonist & $50 \%$ \\
\hline Diuretic & $100 \%$ \\
\hline $\mathrm{CCB}$ & $93 \%$ \\
\hline$A A B$ & $50 \%$ \\
\hline Other & $18 \%$ \\
\hline
\end{tabular}

Continuous variables are presented as means and standard deviations; $\mathrm{AAB}$ - alpha-adrenergic blocker; $\mathrm{ACE}$ - angiotensin converting enzyme; ARB — angiotensin receptor blocker; BMI — body mass index; CCB - calcium channel blocker; DBP — diastolic blood pressure; eGFR — estimated glomerular filtration ratio; SBP — systolic blood pressure

$\mathrm{p}<0.05$ for SBP and $108.0 \pm 18.1$ vs. $94.6 \pm 11.6 \mathrm{~mm} \mathrm{Hg}$, $p<0.005$ for DBP). Office DBP was also increased in patients treated with mineralocorticoid receptor antagonist (105.8 \pm 16.8 vs. $93.8 \pm 12.1 \mathrm{~mm} \mathrm{Hg}, \mathrm{p}<0.001)$ as well as in non-obese subjects ( $104.8 \pm 17.6$ vs. $94.7 \pm 11.9 \mathrm{~mm} \mathrm{Hg}$, $\mathrm{p}<0.05)$.

Mean 24-h SBP was elevated in non-dippers (160.8 \pm 17.8 vs. $148.0 \pm 14.3 \mathrm{~mm} \mathrm{Hg}, \mathrm{p}<0.05)$ and in non-obese patients (159.2 \pm 19.0 vs. $147.8 \pm 12.6 \mathrm{~mm} \mathrm{Hg}, \mathrm{p}<0.05)$. 24-h DBP was higher in patients with increased HR $(100 \pm 16.1$ vs. $84.4 \pm 20.6 \mathrm{~mm} \mathrm{Hg}, \mathrm{p}<0.05)$, non-obese patients (100.2 \pm 17.5 vs. $80.7 \pm 18.5 \mathrm{~mm} \mathrm{Hg}$, $\mathrm{p}<0.001)$, and patients treated with mineralocorticoid receptor antagonist $(98.5 \pm 18.3$ vs. $82.4 \pm 19.4$ mm Hg, $\mathrm{p}<0.01)$.

The median number of antihypertensive drugs was 5.5 (interquartile range: 5.0-7.0). During the follow-up period, the maintenance of the antihypertensive regimen was required unless clinically indicated. Of note, 8 (18.6\%) patients were on a reduced number of medications at 6-month 
follow-up visit and 11 (26.2\%) patients at 12-month visit. In 2 patients, minor changes within the same class of drugs were done. An increased number of drugs was reported in $2(4.7 \%)$ patients at 6 months and in $1(2.3 \%)$ patient at 1 year visit. All those modifications resulted in significant decrease of the median number of hypertensive drugs taken at 6 months (5.0, interquartile range: 5.0-6.0) and 1 year (5.0, interquartile range: $4.0-6.0 ; p<0.05$ and $p<0.01$, respectively, as compared to baseline).

\section{Procedure characteristics}

Mean length and diameter of the renal artery trunk was $35.9 \mathrm{~mm} / 5.9 \mathrm{~mm}$ on the left, and $39.5 \mathrm{~mm} / 5.8 \mathrm{~mm}$ on the right side. The successful procedure, defined as delivery of least four complete, 2-min energy applications to each renal artery, was performed in all 44 patients. The mean number of applications was $5.1 \pm 0.6$ per renal artery. During the procedure, significant vasovagal bradycardia requiring atropine occurred in $12(27 \%)$ patients. There were no any acute complications like artery dissection, abrupt closure, or access site pseudoaneurysm.

\section{Office BP during the follow-up}

Mean reductions of office SBP were $-23.8 \pm 32.1 \mathrm{~mm} \mathrm{Hg}$ after 3 months $(p<0.001),-12.5 \pm 23.4 \mathrm{~mm} \mathrm{Hg}$ after 6 months $(p<0.005)$ and $-12.6 \pm 26.0 \mathrm{~mm} \mathrm{Hg}$ after 1 year $(p=0.005)$, as presented in Figure 1. Additional subanalysis without 8 patients with baseline office SBP below $160 \mathrm{~mm} \mathrm{Hg}$ showed similar reductions of SBP: $-25.9 \pm 33.3,-13.0 \pm 23.0$, and $-13.0 \pm 27.7 \mathrm{~mm} \mathrm{Hg}$ (all significant). The non-responders rate (with SBP reduction less than $10 \mathrm{~mm} \mathrm{Hg}$ ) was $46.5 \%$ at 6 months and $38 \%$ at 12 months. SBP decrease at 12 months was higher in obese patients as compared to non-obese subjects $(-20.3 \pm 17.4 \mathrm{~mm} \mathrm{Hg}$ vs. $-4.1 \pm 31.3 \mathrm{~mm} \mathrm{Hg}$, $\mathrm{p}<0.05)$.

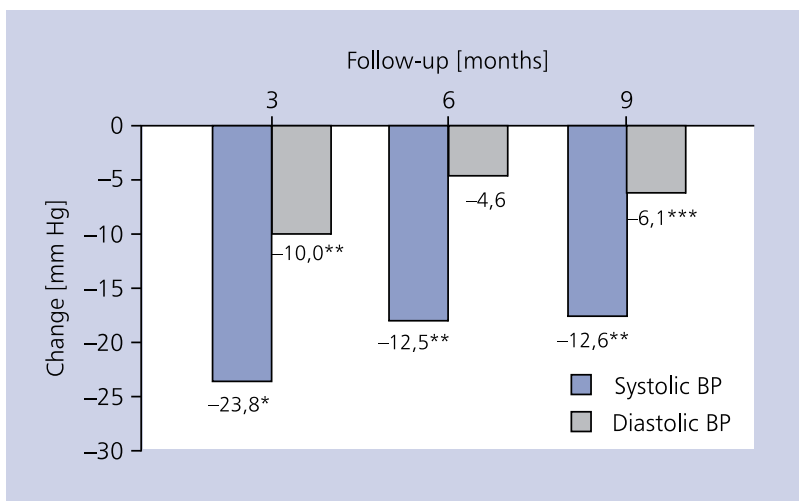

Figure 1. The mean changes of systolic and diastolic blood pressure (BP) after percutaneous renal denervation; ${ }^{*} p<0.0001 ;{ }^{* *} p<0.005 ;{ }^{* * *} p<0.01$
Mean reductions of office DBP were $-10.0 \pm 19.7 \mathrm{~mm} \mathrm{Hg}$ after 3 months ( $p<0.001),-4.6 \pm 16.5 \mathrm{~mm} \mathrm{Hg}$ after 6 months $(p=N S)$, and $-6.1 \pm 14 . \mathrm{mm} \mathrm{Hg}$ after 1 year $(p<0.01)$. Significant difference in DBP reduction at 12 months was detected between patients with increased and normal HR $(-12.8 \pm 14.0 \mathrm{~mm} \mathrm{Hg}$ vs. $-2.5 \pm 13.0 \mathrm{~mm} \mathrm{Hg}$, $\mathrm{p}<0.01)$.

The presence of diabetes was the only predictor of the SBP improvement at 6 months (OR 9.6, 95\% Cl 1.4-66.5, $\mathrm{p}<0.05)$. At 12 months, no significant predictor of SBP response was found.

Significant reductions of pulse pressure were observed at 3 months $(-13.8 \pm 18.9 \mathrm{~mm} \mathrm{Hg}, \mathrm{p}<0.0001), 6$ months $(-7.9 \pm 18.1 \mathrm{~mm} \mathrm{Hg}, \mathrm{p}<0.01)$, and 1 year $(-6.4 \pm 24.3 \mathrm{~mm} \mathrm{Hg}$, $\mathrm{p}<0.05)$ after renal denervation.

\section{4-hour ABPM results at 6 months and 1 year} Mean change of 24-h SBP at 6 months was $-8.3 \pm 19.1 \mathrm{~mm} \mathrm{Hg}$ $(p<0.01)$, and $-4.6 \pm 18.5 \mathrm{~mm} \mathrm{Hg}(p=\mathrm{NS})$ at 12 months. The changes of daytime SBP were significant at 6 months $(-10.6 \pm 20.1 \mathrm{~mm} \mathrm{Hg}, \mathrm{p}<0.0001)$ and 12 months $(-7.4 \pm 20.1 \mathrm{~mm} \mathrm{Hg}, \mathrm{p}<0.05)$ whereas the reduction of night-time SBP was not significant (data not shown). The ABPM non-responders rate (with 24-h SBP reduction less than $5 \mathrm{~mm} \mathrm{Hg}$ ) was $45 \%$ at 6 months and $55 \%$ at 12 months.

Mean change of $24-\mathrm{h}$ DBP at 6 months was $-2.9 \pm 17.5$ $(p<0.05)$ and $-1.2 \pm 17.3 \mathrm{~mm} \mathrm{Hg}(p=N S)$ at 12 months. The reduction of daytime DBP was $-6.3 \pm 12.5 \mathrm{~mm} \mathrm{Hg}(\mathrm{p}<0.01)$ at 6 months and $-4.1 \pm 13.9 \mathrm{~mm} \mathrm{Hg}(p=N S)$ at 1 year. The night-time DBP changes were non significant (not presented).

Twenty-four-hour SBP and DBP reductions were significant in patients with increased baseline HR both at 6 months $(-15.9 \pm 19.9 \mathrm{~mm} \mathrm{Hg}, \mathrm{p}<0.01 /-10.2 \pm 14.3 \mathrm{~mm} \mathrm{Hg}$ $\mathrm{p}<0.05)$ and at 1 year $(-11 \pm 18.2 \mathrm{~mm} \mathrm{Hg}-7.4 \pm 13.0 \mathrm{~mm} \mathrm{Hg}$, both $\mathrm{p}<0.05)$. In multivariate analysis, increased $2-\mathrm{h}$ glucose concentration measured in OGTT was the only predictor of 24-h SBP response at 6 months (OR 1.24 for each $10 \mathrm{mg} / \mathrm{dL}$ increase in glucose concentration, $95 \% \mathrm{Cl}$ 1.04-1.48, p < 0.05). At 12 months, the predictors of 24-h SBP decrease were: higher baseline office SBP (OR 4.93 for $10 \mathrm{~mm} \mathrm{Hg}$ increment in SBP, 95\% Cl 1.01- 24.1, $\mathrm{p}<0.05$ ) and increased 2-h glucose in OGTT (OR 1.47 for each $10 \mathrm{mg} / \mathrm{dL}$ increase in glucose concentration, $95 \% \mathrm{Cl}$ 1.08-2.00, $p<0.05$ )

\section{Heart-rate changes}

Significant decrease in HR was observed at 6 months $(-5.2 \pm 15.4$ bpm, $p<0.05)$ but non-significant at 12 months in all subjects $(-2.3 \pm 12.4 \mathrm{bpm}, \mathrm{p}=\mathrm{NS})$. HR reduction after renal denervation was related to baseline HR. In patients with increased baseline HR, the HR reductions were $-17.3 \pm 14.4 \mathrm{bpm}(\mathrm{p}<0.005)$ at 6 months and 
Table 2. Changes (means and standard deviations) in fasting and 2-h glucose concentration in relation to 24-h systolic blood pressure response

\begin{tabular}{|c|c|c|c|}
\hline Variable & ABPM — responders & ABPM — non-responders & $\mathbf{P}$ \\
\hline \multicolumn{4}{|c|}{ Fasting plasma glucose [mg/dL]: } \\
\hline At baseline & $96.2 \pm 18.1$ & $95.7 \pm 22.1$ & NS \\
\hline At 6 months & $95.4 \pm 19.5$ & $111.7 \pm 40.2$ & NS \\
\hline Change & $-0.4 \pm 20.9$ & $15.3 \pm 25.9^{*}$ & NS $(0.054)$ \\
\hline \multicolumn{4}{|c|}{ 2-h glucose in OGTT $[\mathrm{mg} / \mathrm{dL}]$ : } \\
\hline At baseline & $186.5 \pm 68.3$ & $117.3 \pm 45.6$ & $<0.005$ \\
\hline At 6 months & $149.5 \pm 51.9$ & $135.4 \pm 49.8$ & NS \\
\hline Change & $-41.7 \pm 47.0^{*}$ & $17.8 \pm 50.7$ & $<0.005$ \\
\hline
\end{tabular}

${ }^{*} \mathrm{p}<0.01 ; \mathrm{ABPM}$ - ambulatory blood pressure monitoring; OGTT — oral glucose tolerance test

$-11.9 \pm 7.8 \mathrm{bpm}(\mathrm{p}<0.0001)$ at 12 months, and they were significantly higher than those seen in subjects with baseline HR below 80 bpm ( $p$ for comparison $<0.0001$ at 6 and at 12 months).

\section{Metabolic and kidney parameters changes at 6 months}

There were no significant changes in metabolic parameters at 6 months after renal denervation: non significant decrease in 2-h glucose concentration in OGTT $(-14.2 \pm 56.6 \mathrm{mg} / \mathrm{dL})$, slight increase of fasting plasma glucose $(5.6 \pm 4.7 \mathrm{mg} / \mathrm{dL})$, and no change in $\mathrm{HbA} 1 \mathrm{c}$ level were observed $(0.1 \pm 0.7 \%)$. Significant difference in $\mathrm{HbA} 1 \mathrm{c}$ change was observed only between younger $(<55$ years) and older patients $(-0.2 \pm 0.5 \%$ vs. $0.5 \pm 0.7 \%$, respectively, $p<0.05)$. However, a remarkable relationship between the changes in glucose metabolic parameters and ABPM response was found. In subgroups of ABPM-responders, a significant reduction of 2-h glucose in OGTT was found as compared to the non-responders $(-41.7 \pm 47.0 \mathrm{mg} / \mathrm{dL}$ vs. $17.8 \pm 50.7 \mathrm{mg} / \mathrm{dL}, \mathrm{p}<0.005)$. Plasma fasting glucose concentration increased in ABPM non-responders and remained stable in the responders subgroup, as presented in Table 2 .

Mean changes of eGFR were $4.6 \pm 21.6 ; 6.4 \pm 21.3$ and $1.2 \pm 21.9 \mathrm{~mL} / \mathrm{min}$ per $1.73 \mathrm{~m}^{2}$ at 3,6 , and 12 months, respectively. The change of eGFR was not associated with BP response. No significant renal artery stenosis was found on ultrasonography at 6 months.

\section{DISCUSSION}

The results of the RDN-POL Registry show that in patients with confirmed in ABPM resistant hypertension, catheter-based renal denervation therapy causes moderate reduction in office SBP. The reductions of pulse pressure were also significant, but the changes of DBP were rather modest. Additionally, ABPM recordings showed only small BP decrease at 6 months, and no significant change at 1 year after renal denervation. In initial clinical trials — randomised Symplicity HTN-2 and non-ran- domised Symplicity HTN-1 study - observed reductions in office SBP were about $30 \mathrm{~mm} \mathrm{Hg}[2,3]$. However, in contrast to our registry, neither protocol required ABPM recordings for "true-resistance" confirmation. The results in ABPM measurements are less impressive but are consistent with the recently published, largest randomised, sham-controlled Symplicity HTN-3 trial, including 535 patients with ABPM-confirmed resistant hypertension [4]. In the Symplicity HTN-3 trial, the decrease of SBP in ABPM at 6 months was lower than in our Registry $(-6.75 \mathrm{~mm} \mathrm{Hg}$ vs. $-8.3 \mathrm{~mm} \mathrm{Hg}$ ).

The RDN-POL Registry reflects real-world patient results rather than first clinical trials data, like those obtained in the Symplicity HTN-1 and Symplicity HTN-2 trials. For comparison, in a report by Id et al. [8] the 6-month reduction in office SBP in 54 patients after bilateral denervation of single renal arteries was $16.6 \mathrm{~mm} \mathrm{Hg}$. The change in 24-h SBP was identical to our result $(-8.3 \mathrm{~mm} \mathrm{Hg})$. Similarly, Volz et al. [9] reported a 17-mm Hg reduction in office SBP, but only a 6-mm Hg change in ABMP recordings. Recent meta-analysis of 7 randomised-control studies demonstrated a 16.5-mm Hg decrease of office and 9.2-mm Hg of 24-h SBP [10]. By contrast, Mahfoud et al. [11] demonstrated excellent office SBP reduction by 23.7 and $27.3 \mathrm{~mm} \mathrm{Hg}$ after 6 and 12 months in 303 patients with true-resistant hypertension. However, in that study the 24-h SBP changes were also less pronounced (-10 and $-11.7 \mathrm{~mm} \mathrm{Hg}$, respectively).

In our report, the strongest predictors of SBP response evaluated in ABPM recordings were baseline office SBP and baseline 2-h glucose concentration in OGTT. Every $10-\mathrm{mm} \mathrm{Hg}$ increase of baseline office SBP was associated in almost 5 -fold higher probability of significant SBP reduction in ABPM after 1 year. Notably, every $10-\mathrm{mg} / \mathrm{dL}$ rise in 2-h glucose level in OGTT increased that probability by $24 \%$ at 6 months and by $47 \%$ at 12 months after renal denervation. Moreover, the 2-h glucose concentration in OGTT was substantially reduced after 6 months in the subgroup of ABPM-responders. It supports the hypothesis that efficient renal denervation may also diminish insulin resistance resulting from sympathetic 
adrenergic hyperactivity. It has been shown that inhibition of the sympathetic nervous system by moxonidine improved glucose metabolism by decreasing glucagon secretion and increasing skeletal blood flow with less glycogenolysis and gluconeogenesis [12]. It confirmed a pathophysiological association between the central nervous system and insulin resistance. Our data are consistent with the results of two previously published trials, suggesting a beneficial effect of renal denervation on indices of glucose metabolism [13, 14].

Increased SBP was an independent predictor of BP reduction in the abovementioned study of Mahfoud et al. [11] and in Symplicity HTN-3, where also aldosterone antagonist use and non-use of vasodilators remained significant predictors in multivariate analysis [15]. In other trial, higher 24-h SBP predicted BP improvement [16]. In the presented registry, such a correlation was not found, which may be due to the small patient cohort. The report of Zuern et al. [17] also suggested that baroreflex sensitivity test may predict hypertension response after renal denervation.

Interestingly, in our patients with true-resistant hypertension, renal denervation was also accompanied by a reduction of HR, especially in patients with baseline HR over $80 \mathrm{bpm}$. Moreover, 24-h SBP and DBP reductions were more significant in patients with increased baseline HR. It confirms that increased $H R$ reflects excessive sympathetic nervous system activity and may indicate patients deriving benefit from renal denervation.

Our study confirmed the safety of percutaneous renal denervation. No access site complications and no serious procedure-related complications were reported. Also, small changes in eGFR during the follow-up period confirmed the safety of the procedure.

\section{Limitations of the study}

The RDN-POL Registry has a number of limitations that may influence its results. Firstly, in our trial, about $25 \%$ of patients changed their recommended antihypertensive drugs regimen during the follow-up period, in most cases by reduction of the number of drugs taken. It could increase BP results obtained at follow-up visits and diminish the effect of renal denervation on the hypertension treatment. However, subanalysis of the patients maintained on baseline drugs regimen did not reveal better BP response after renal denervation (not presented). For comparison, in the Symplicity HTN-3 trial, $40 \%$ of patients changed the medications after the procedure, and the reduction of the BP was not associated with the hypertension treatment modification.

Secondly, this is a non-randomised, single-arm study with a modest sample size, which does not allow us to draw definitive conclusions.

Thirdly, it should be mentioned that the majority of sites (9 of 11) were not experienced in renal denervation procedure before entering into the registry. Only two sites had participated previously in the Symplicity HTN-1 or HTN-2 trials. As no roll-in phase had been introduced, procedures were performed by operators who were experienced with endovascular techniques, but who were novices in renal denervation technique. Despite the majority of the procedures being supervised by the experienced proctor, this fact could have had impact on the level of the completeness and effectiveness of the procedures. The results of single site studies and registries demonstrated better results of renal denervation procedures performed by experienced operators [18, 19].

Finally, it may be hypothesised that the maximum number of 6 discrete applications as limited by the protocol was probably insufficient. As Kandzari et al. [15] demonstrated in their Symplicity HTN-3 analysis, the BP reduction was linearly correlated with the higher number of ablations and with energy delivery in a four-quadrant pattern. The best results were achieved in subjects with more than 12 applications done in both arteries. It should also be emphasised that no tests are available allowing assessment of proper wall contact and effective destruction of renal nerves during or after the procedure. In tortuous renal arteries it is more difficult to obtain appropriate contact of the catheter's tip with the vessel wall assuring proper energy delivery to the nerve fibres located in the adventitia. Probably, the new helical multi-electrode catheter will improve the electrodes apposition and provide better vessel wall heating.

\section{CONCLUSIONS}

In conclusion, the RDN-POL Registry demonstrated that the reductions in office $\mathrm{BP}$ up to $30 \mathrm{~mm} \mathrm{Hg}$ observed in first clinical studies may be difficult to obtain in real-world patients. The office BP improvement is moderate, and the renal denervation is rather a complementary method of treatment than an alternative to the standard pharmacotherapy. Renal denervation also decreases $\mathrm{HR}$, especially in patients with baseline increased pulse rate. Interestingly, a subanalysis of patients with adequate BP response in ABPM indicates that renal denervation may have a positive impact on glycaemic control. Further studies in this field of research are warranted.

\section{Acknowledgements}

Acknowledgements to all of the Investigators: Florczak $E$, Prejbisz A, Kądziela J, Januszewicz A, Witkowski A, Chrostowska M, Szyndler A, Narkiewicz K, Kochman J, Roik M, Opolski G, Zajdel W, Niewiara L, Sadowski J, Olszanecka A, Styczkiewicz K, Jankowski P, Czarnecka D, Mielecki W, Dudek D, Gziut A, Kosior D, Krzyżewski R, Gil R, Czerwieńska B, Więcek A, Kostka-Jeziorny K, Grajek S, Tykarski A, Buchta P, Lekston A, Czarnopyś-Sitarz A, Dąbrowski P, Kleinrok A, Turek A, Milewski K, Buszman P.

Funding source: The RDN-POL Registry was designed by physicians from 11 Polish centres and coordinated by the Institute of Cardiology, Warsaw. This "non-profit" registry was supported by the donation of Symplicity catheters and funds for 
Ethics Committee evaluation and secretarial work by Medtronic Poland. The founder did not participate in the design of the study or analysis of data.

Conflict of interest: Jacek Kądziela, Aleksander Prejbisz, Andrzej Januszewicz declared lecture fees and per-patient payment for study involvement from Ardian-Medtronic; Katarzyna Kostka-Jeziorny declared lecture fees from Medtronic; Krzysztof Narkiewicz declared lecture and consultancy fees from Medtronic; Adam Witkowski declared Speaker's Bureaux and clinical trial fees form Medtronic; other authors did not declare conflict of interest; Dariusz Dudek, Jerzy Sadowski, Andrzej Lekston, Aneta Gziut, Andrzej Więcek, Paweł Buszman, Andrzej Kleinrok, Janusz Kochman, Danuta Czarnecka — none declared.

\section{References}

1. Krum H, Schlaich M, Whitbourn R, Sobotka PA et al. Catheter-based renal sympathetic denervation for resistant hypertension:a multicentre safety and proof-of-principle cohort study. Lancet, 2009; 373: 1275-1281. doi: 10.1016/S0140-6736(09)60566-3.

2. Symplicity HTN-1 Investigators. Catheter-based renal sympathetic denervation for resistant hypertension: durability of blood pressure reduction out to 24 months. Hypertension, 2011; 57: 911-917. doi: 10.1161/HYPERTENSIONAHA.110.163014.

3. Esler MD, Krum H, Sobotka PA et al. Renal sympathetic denervation in patients with treatment-resistant hypertension (The Symplicity HTN-2 Trial): a randomised controlled trial. Lancet, 2010; 376: 1903-1909 doi: 10.1016/S0140-6736(10)62039-9.

4. Bhatt DL, Kandzari DE, O'Neill WW et al. SYMPLICITY HTN-3 Investigators. A controlled trial of renal denervation for resistant hypertension. NEngl J Med, 2014; 370: 1393-1401. doi: 10.1056/NEJMoa1402670.

5. Januszewicz A, Witkowski A. Renal denervation - where do we stand in 2014? Post Kardiol Interw, 2014; 10: 1. doi: 10.5114/pwki.2014.41457.

6. Warchoł-Celińska E, Januszewicz A, Prejbisz A, Kądziela J. Renal denervation after the symplicity HTN-3 trial. Post Kardiol Interw, 2014; 10: 75-77. doi: 10.5114/pwki.2014.43509.

7. Levey AS, Coresh J, Greene T et al. Using standardized serum creatinine values in the modification of diet in renal disease study equation for estimating glomerular filtration rate. Ann Intern Med, 2006; 145: 247-254.

8. Id D, Kaltenbach B, Bertog SC Does the presence of accessory renal arteries affect the efficacy of renal denervation? J Am Coll
Cardiol Cardiovasc Interv, 2013; 6: 1085-1091. doi: 10.1016/j. jcin.2013.06.007.

9. Völz S, Andersson B, Manhem K et al. Effect of catheter-based renal sympathetic denervation on 24-h ambulatory blood pressure in patients with resistant hypertension. Blood Press, 2014; 23: 228-232. doi: 10.3109/08037051.2013.867663

10. Fadl Elmula FE, Jin Y, Yang WY et al. European Network Coordinating Research On Renal Denervation (ENCOReD) Consortium. Meta-analysis of randomized controlled trials of renal denervation in treatment-resistant hypertension. Blood Press, 2015; 24 : 263-274. doi: 10.3109/08037051.2015.1058595.

11. Mahfoud F, Ukena C, Schmieder RE et al. Ambulatory blood pressure changes after renal sympathetic denervation in patients with resistant hypertension. Circulation, 2013; 128: 132-40. doi: 10.1161/CIRCULATIONAHA.112.000949.

12. Yakubu-Madus FE, Johnson WT, Zimmerman KM et al. Metabolic and hemodynamic effects of moxonidine in the Zucker diabetic fatty rat model of type 2 diabetes. Diabetes, 1999; 48: 1093-1100.

13. Mahfoud F, Schlaich M, Kindermann I et al. Effect of renal sympathetic denervation on glucose metabolism in patients with resistant hypertension: a pilot study. Circulation, 2011; 123: 1940-1946. doi: 10.1161/CIRCULATIONAHA.110.991869.

14. Witkowski A, Prejbisz A, Florczak E et al. Effects of renal sympathetic denervation on blood pressure, sleep apnea course, and glycemic control in patients with resistant hypertension and sleep apnea. Hypertension, 2011; 58: 559-565. doi: 10.1161/HYPERTENSIONAHA.111.173799.

15. Kandzari DE, Bhatt DL, Brar $S$ et al. Predictors of blood pressure response in the Symplicity HTN-3 trial. Eur Heart J, 2015; 36: 219-227. doi: 10.1093/eurheartj/ehu441.

16. Prochnau D, Heymel S, Göbel B et al. Resistant hypertension: multi-variate predictors of blood pressure response to renal denervation. Int J Cardiol, 2013; 168: 3130-3132. doi: 10.1016/j. ijcard.2013.04.035.

17. Zuern CS, Eick C, Rizas KD et al. Impaired cardiac baroreflex sensitivity predicts response to renal sympathetic denervation in patients with resistant hypertension. J Am Coll Cardiol, 2013; 62: 2124-2130. doi: 10.1016/j.jacc.2013.07.046.

18. Vogel B, Kirchberger M, Zeier M et al. Renal sympathetic denervation therapy in the real world: results from the Heidelberg registry. Clin Res Cardiol, 2014; 103: 117-124. doi: 10.1007/s00392-013-0627-5

19. Bartuś K, Sadowski J, Kapelak B et al. Denervation of nerve terminals in renal arteries: one-year follow-up of interventional treatment of arterial hypertension. Kardiol Pol, 2014; 72: 425-431. doi: 10.5603/KP.a2013.0357.

Cite this article as: Kądziela J, Prejbisz A, Kostka-Jeziorny K et al. Effects of renal sympathetic denervation on blood pressure and glycaemic control in patients with true resistant hypertension: results of Polish Renal Denervation Registry (RDN-POL Registry). Kardiol Pol, 2016; 74: 961-968. doi: 10.5603/KP.a2016.0058. 


\section{Wpływ denerwacji nerek na wartość ciśnienia tętniczego i kontrolę glikemii u pacjentów z prawdziwie opornym nadciśnieniem tętniczym: wyniki Polskiego Rejestru Denerwacji (RDN-POL)}

Jacek Kądziela1 , Aleksander Prejbisz², Katarzyna Kostka-Jeziorny³, Dariusz Dudek², Krzysztof Narkiewicz' Jerzy Sadowski ${ }^{6}$, Andrzej Lekston ${ }^{7}$, Aneta Gziut ${ }^{8}$, Andrzej Więcek ${ }^{9}$, Paweł Buszman ${ }^{10}$, Andrzej Kleinrok ${ }^{11}$, Janusz Kochman ${ }^{12}$, Danuta Czarnecka ${ }^{13}$, Andrzej Januszewicz ${ }^{2}$, Adam Witkowski ${ }^{1}$

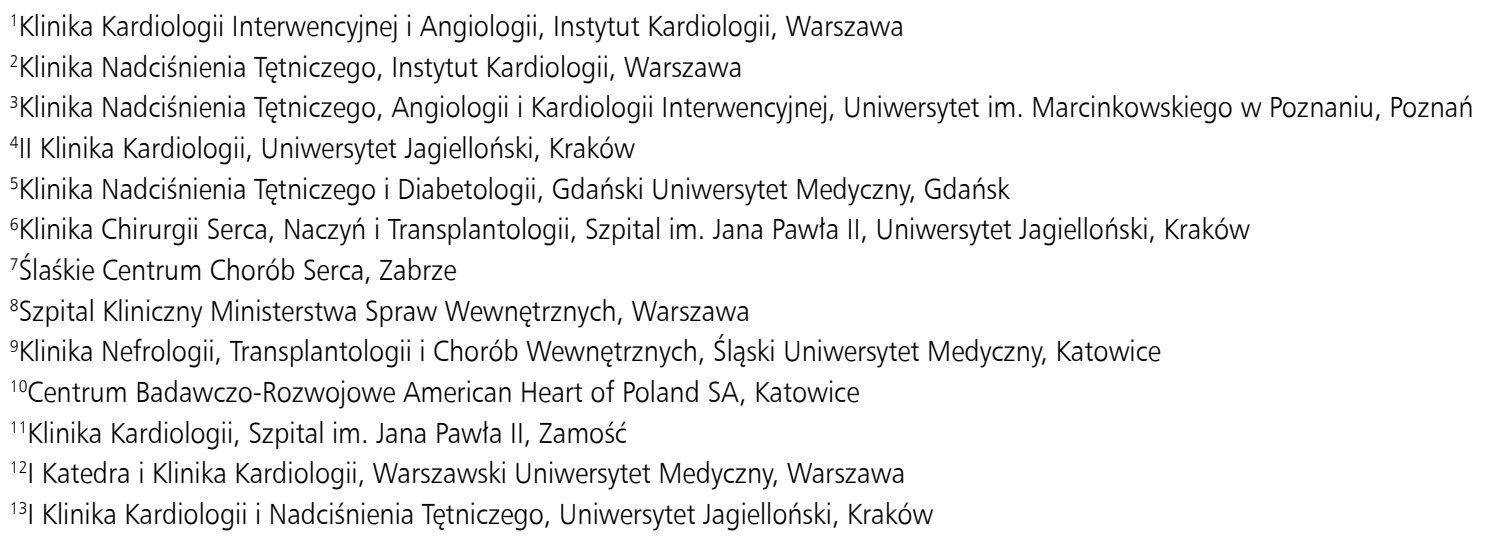

Streszczenie

Wstęp i cel: Celem niniejszej pracy była ocena skuteczności przezskórnej denerwacji nerek (RDN) u pacjentów z prawdziwie opornym nadciśnieniem tętniczym oraz przedstawienie wyników Polskiego Rejestru Denerwacji - RDN-POL.

Metody: U 44 pacjentów z prawdziwie opornym nadciśnieniem tętniczym (23 mężczyzn, mediana wieku 55 lat) ze skurczowym ciśnieniem tętniczym (SBP) w 24-godzinnym pomiarze ambulatoryjnego ciśnienia tętniczego (ABPM) $\geq 135 \mathrm{~mm} \mathrm{Hg}$, leczonych co najmniej 3 lekami hipotensyjnymi, w tym diuretykiem, wykonano RDN. Okres obserwacji wyniósł 12 miesięcy po zabiegu. Wyniki: Zaobserwowano średnią redukcję ciśnienia tętniczego w pomiarach gabinetowych o-23,8/-10,0; -12,5/-4,6 i-12,6/ /-6,1 mm Hg po odpowiednio 3, 6 i 12 miesiącach obserwacji (wszystkie znamienne statystycznie oprócz zmiany rozkurczowego ciśnienia tętniczego po 6 miesiącach). Obecność cukrzycy była jedynym predyktorem redukcji SBP w pomiarach gabinetowych po 6 miesiącach (OR 9,6; 95\% Cl 1,4-66,5; p < 0,05). Średnia redukcja SBP w ciągu doby w ABPM wyniosła $-8,3 \mathrm{~mm} \mathrm{Hg}$ po 6 miesiącach oraz $-4,6 \mathrm{~mm} \mathrm{Hg}$ po 12 miesiącach od zabiegu. Zwiększone stężenie glukozy w doustnym teście obciążenia glukozą okazało się predyktorem redukcji SBP w ABPM po 6 miesiącach (OR 1,24 na każdy wzrost glikemii o $10 \mathrm{mg} / \mathrm{dl} ; 95 \%$ Cl 1,04-1,48; p < 0,05). Po 12 miesiącach predyktorami zmiany SBP w pomiarze ABPM były: wyjściowe SBP w pomiarach gabinetowych przed zabiegiem (OR 4,93 na każdy wzrost SBP o $10 \mathrm{~mm} \mathrm{Hg}, 95 \% \mathrm{Cl}$ 1,01-24,1; p < 0,05) i stężenie glukozy w teście obciążenia glukozą (OR 1,47; 95\% Cl 1,08-2,00; $\mathrm{p}<0,05)$. U osób z uzyskaną co najmniej 5-mm Hg redukcją SBP w ABPM (tzw. responders), zaobserwowano istotne zmniejszenie glikemii w teście obciążenia glukozą w porównaniu z osobami bez spadku SBP w ABPM $(-45,8$ vs. $-7,7 \mathrm{mg} / \mathrm{dl} ; \mathrm{p}<0,005)$.

Wnioski: Wyniki rejestru RDN-POL wskazują na umiarkowaną redukcję ciśnienia tętniczego uzyskaną po RDN. Predyktorami poprawy kontroli ciśnienia tętniczego okazały się: obecność cukrzycy, glikemia w teście obciążenia glukozą i wartość SBP przed zabiegiem. Analiza osób z istotną redukcją SBP w pomiarach ABPM wskazuje na potencjalny korzystny wpływ RDN na poprawę profilu glikemicznego.

Słowa kluczowe: oporne nadciśnienie tętnicze, denerwacja nerek, rejestr, cukrzyca, współczulny układ nerwowy

Kardiol Pol 2016; 74, 9: 961-968 